\title{
Universo Entreaberto
}

\section{Ana Gerdau de Borja}

A cada passo, deparamo-nos com um universo de emoçőes, pessoas, ambientes, paisagens, dados... E ter estudado Direito por cinco meses na Universidade do Texas fez-me mais aberta para o plural e para o novo. Digo "universo entreaberto", porque ainda há muito a ser percorrido, pois Direito é um oceano, é infinito:

A Faculdade de Direito da Universidade do Texas está entre as dez melhores dos EUA, e não é por acaso. $O$ grupo docente é destacadíssino em âmbito nacional e, até mesmo, internacional. Por sua vez, o grupo discente também é excepcional. Quanto à Universidade como um todo, a infraestrutura oferecida no campus é maravilhosa, parece até uma mini-cidade.

A densidade das aulas que cursei foi excelente, porquanto se vislumbrou uma bela noção do șistema da common law. Muito embora haja em certas matérias forte tendência à regulamentaçăo através de leis, a compreensão da sistemática do estudo de casos foi de grande valia. Dentre as disciplinas que cursei, do passo que a matéria International Litigation \& Arbitration (Direito Processual Internacional e Arbitragem) é mormente baseada em casos, Business Associations (Direito Societário), Comparative Environmental Law (Direito Ambiental Comparado), Intellectual Property (Direito da Propriedade Intelectual) apresentam forte tendênciaa un maior desenvolvimento de legislação.

Como se sabe, a metodologia empregada nas aulas é a do famoso método socrático. Creio que experienciei um método socrático mais atenuado e, na minha opiniāo, mais apropriado. Explico: o método socrático atenuado não se funda no "terror", nem mesmo na "humilhação" do aluno que não é capaz de responder adequadamente à provocação do professor realizada através de perguntas. Muito pelo contrário, trata-se de um método de elevada modernidade e de louvável eficiência. O entusiasmo e a seriedade do professor, as perguntas que guiam o raciocínio da aula, a preparaçăo dos alunos, feita através dos famosos assignments (leituras prévias obrigatórias), provocam uma sinergia imensamente proveitosa para todos os partícipes do processo de aprendizado: acadêmicos e professores.

\footnotetext{
Ana Gerdau de Borja foi contemplada com bolsa da CAPES durante o semestre cursado na University of Texas al Austin, de janeiro a maio de 2004, através do Consórcio CAPES-FIPSE de Educação Superior Brasil-Estados Unidos - O Futuro do Principlo da Precaução no Direito Ambiental do Brasil e dos Estados Unidos (Intercâmbio de Graduação entre as Faculdades de Direito da Universidade Federal do Rio Grande do Sul (UFRGS) e da University of Texas at Austin).
} 
É bem verdade que a pressão é aquela de o professor perguntat diretamente ao estudante para que expresse sua opiniāo. Contudo, caso ele não for capaz de responder, com naturalidade chama-se outro aluno para substitui-lo. $O$ sistema que preferi foi o de minha aula de Direito da Propriedade Intelectual, uma vez que a discussão era táo apaixonante que os alunos se voluntariavam a participar, sem que o professor sequer os chamasse.

Como bem ressaltou un de meus professores, Russel Weintraub: "não pretendo testar a memória de vocês, mas seu raciocínio." E é exatamente o que ocorreu. As três provas que fiz foram com consulta, com questões acerca da solução de casos jurídicos de alta complexidade. Duas delas foram "take-home", isto é, não foram feitas em sala de aula, pois tive para uma, nove horas, e para outra, doze horas de prova. Destarte, os estudantes passam na biblioteca durante este período, concentrados na resolução de problemas jurídicos. Por não ter inglês como língua-mãe, tive metade do tempo a mais que os outros estudantes americanos-como também tiveram os outros colegas estrangeiros.

Para outras duas disciplinas redigi dois papers. Um deles foi sobre Direito Societário, em que fiz uma análise comparativa sobre a legislação societária brasileira e norte-americana acerca da legislação de combate a fraudes, tendo em vista a proteçáo dos investidores no mercado de capitais desses países. Também, para a disciplina a que assisti como ouvinte, International Business Litigation (Direito Processual Comercial Internacional), ministrada pelo Prof. Jay Westbrook, escrevi um trabalho sobre "Leis de Aplicação Imediata do Direito da Propriedade Intelectual e a Arbitrabilidade nos Estados Unidos e no Brasil." A idéia de escrever sobre o assunto nasceu durante minha experiência como bolsista da Academia de Direito Internacional de Haia em julho de 2003, e foi aperfeiçoada com as aulas que tive no Texas, em especial com os professores Russel Weintraub e Jay Westbrook acerca de Arbitragem, bem como com o professot Oren Bracha, de Direito da Propriedade Intelectual.

Sem dúvida, a biblioteca é uma das melhores dos EUA e realmente incrível. Não bastasse a riqueza e a variedade de obras jurídicas do próprio país e de muito outros, ela conta com recantos de estudo belíssimos, vez que também é a sede de uma coleção de arte, contando com pinturas, tapetes, bem como outras relíquias e raridades.

A organização da Faculdade de Direito é algo que chama a atenção, e a impressão não é diferente quanto à riqueza de recursos oferecidos aos alunos. Por exemplo, os professores oferecem as chamadas office hours, em que ficam à disposiçâo dos alunos para dúvidas durante determinados períodos da semana. Há também um sistema chamado blackboard, através do qual os professores deixam on-line mensagens para os alunos acerca das leituras recomendadas, trabalhos, provas, e onde também é possível estabelecer um chat de conversa entre professores e acadêmicos, com acesso por todos os alunos inscritos na disciplina. 
Outrossim, a Faculdade de Direito oferece aos alunos gratuitamente atendimento no chamado Writing Center, em que uma pessoa especializada em corrigir trabalhos jurídicos ficá à disposição dos alunos-para mim foi essencial, por ter escrito dois trabalhos em inglês. A Universidade também proporciona a todos os estudantes acesso a dois centros esportivos, para que se siga à risca o brocardo "mens sana in corpore sano."

Enfim, aprendi que nosso país precisa de mais pessoas que acreditem em qualificaçāo, em nossas instituições. Eé pacífico que a descrença nas próprias instituiçôes levam os países à decadência e a ditaduras. Os EUA configuram o oposto disso. Trabalha-se muito, é-se altamente democrata, leva-se a Faculdade com imensa seriedade e ética, com dedicação exclusiva-talvez até porque os estudantes tiram empréstimos para poderem cursar Universidades como a do Texas.

Um aspecto que talvez deva ser ressaltado é a seriedade e a ética com que os estudantes se dedicam à Faculdade de Direito. Logo que entrei, assinei um termo de ciência do Honor Code, isto é, do Código de Honra da Faculdade, como também outro termo de ciência no tocante à vedação ao plágio por parte dos alunos. Isto me chamou muito a atenção. Tal Código de Honra estabelece que "os estudantes que tomassem atitudes antiéticas em relação às provas e aos colegas eram perigosos e nocivos nẵo só ao meio acadêmico, mas à sua profissão e à sociedade como um todo." E isto é a mais pura verdade, não só no que toca aos cursos de Direito, mas a todas as outras áreas.

Outro ponto a ser destacado é o da administração das provas. As provas não são aplicadas pelos professores, mas por uma equipe de funcionários da Faculdade. Na minha opinião, isto constitui um fator essencial à seriedade do sistema. Aplicar prova é algo administrativo, e que não deveria ser tarefa do professor-que acaba se sujeitando a situações constrangedoras sen por quê.

Em suma, o interessante é que esta experiência que tive nos EUA, embora tenha durado apenas por cinco meses, em verdade para mim correspondeu a mais de ano, tamanha a intensidade do aprendizado. Aprendi muito não só sobre direito, mas sobre outra cultura tão diferente da nussa, e sobre a vida. E como crescemos como pessoa, como seres humanos!

E o mais brithante de toda esta experiência foi avistar novos horizontes em matéria de direito: Direito Ambiental, com o Prof. Hermann Benjamin (que é Professor Visitante na Universidade do Texas), Direito da Propriedade Intelectual, Direito Processual Internacional, Direito da Concortência...

Por derradeiro, para encerrar com chave de ouro esta experiencia nos EUA, minha colega, Tâmara Joana Biolo Soares, e eu, participamos da competição que simula a Corte Interamericana de Direitos Humanos, Inter-American Moot Court Competition, organizada pela American University, em Washington DC (nos dias 23 a 28 de maio deste ano, 2004). Assim, representamos nossa Universidade na 
competição que neste ano versou sobre Direito Ambiental, tema deste Convênio, tendo recebido a premiação de Melhor Memorando em Português.

Neste contexto, foi maravilhoso conhecer de perto o Sistema Interamericano de Direitos Humanos, mediante o estudo de um caso fictício, associando diretamente Direitos Humanos e Direito Ambiental. As aulas do Prof. Hermann Benjamin e minha querida colega Tâmara motivaram-me nesta nova empreitada, importantíssima para mim, eis que nos últimos três anos tenho enfocado imensamente a área de Direito Internacional Privado, Contratos Internacionais e Arbitragem.

Vishumbro, então, que a minha paixão pelo viés "internacional" do Direito levou-me como uma "onda" do Direito Internacional Público ao Direito Internacional Privado (entrei na Faculdade de Direito com o objetivo de seguir a carteira diplomática). E tal onda vai e volta, tanto que esta experiência na simulaçäo da Corte Interamericana me fez regressar ao Direito Intemacional Público. E que bela é a compreensão de que esses Direitos estão todos entrelaçados: o elemento público na vida privada das pessoas, e vice-versa.

Enfim, foi uma grande honra ter sido bolsista da CAPES, ciente do grande esforço do governo brasileiro para viabilizar esta experiencia, vez que há tantas outras pessoas que precisam mais do que eu própria. E minha honra só engrandece ao saber que meu país investe nos jovens estudantes, com tamanha visão estratégica!

Sinceramente,

Ana Gerdau de Borja

Porto Alegre, 18 de julho de 2004. 